\title{
O diálogo inter-religioso para uma ecologia integral: estudo sobre a contribuição do Papa Francisco especialmente com a Laudato Sí para o diálogo inter-religioso
}

\author{
Orientadora: Maria Teresa de Freitas Cardoso \\ Mestrando: Chrystiano Gomes Ferraz \\ Área de Concentração: Teologia Sistemático-Pastoral \\ Linha de Pesquisa: Fé e Cultura \\ Projeto de Pesquisa: Laudato Si' no antropoceno: ecologia integral \& \\ arquitetura do cuidado ecumênico
}

A contribuição do Papa Francisco para o diálogo inter-religioso, em especial na sua Carta Encíclica Laudato Si'é o tema principal desta dissertação. Foi feita uma exposição sobre o tema do diálogo inter-religioso em geral, através de obras de referência para esta temática, a fim de compreender os desafios e a importância do diálogo em tempos de pluralismo religioso e crise sócio-ecológica. Assim, foi preparado o terreno para posicionarmos as contribuições do Papa Francisco ao tema do diálogo inter-religioso, caracterizando sua atuação em prol do "diálogo da fraternidade", na amizade e caminhada conjunta, que vai em busca do enriquecimento mútuo e bem comum, trabalhando em favor da paz, justiça social, tolerância e liberdade religiosa. Utilizou-se primeiramente como base a Exortação Apostólica Evangelii Gaudium, conteúdo programático de seu pontificado que prevê a prática do diálogo inter-religioso como parte da missão evangelizadora da Igreja Católica. Chegou-se ao entendimento de que o diálogo inter-religioso está dentro da prática pastoral de Francisco. Levantou-se então a pergunta-hipótese: há em Francisco uma contribuição original e singular para o tema do diálogo inter-religioso atual? Questão respondida positivamente. Através da análise da Laudato Si', cons- 
tatou-se uma contribuição original de Francisco para a temática do diálogo inter-religioso, a construção de uma ecologia integral como tema de reflexão, encontro e colaboração inter-religiosas. Esta pesquisa integra-se no Projeto de Pesquisa sobre a Laudato Si' coordenado pela professora orientadora.

Palavras-chave: Diálogo inter-religioso. Ecologia integral. Ecoteologia. Laudato Si'. Papa Francisco. 